\title{
Halkla İlișkiler ve Tanıtım Programlarında Öğrenim Gören Öğrencilerin Yakınlarının Halkla İlișkiler Mesleği Konusunda Tutum ve Algıları Üzerine Bir Araștırma
}

\author{
Gonca Yildırım ${ }^{1}$ \\ Deniz Akbulut ${ }^{2}$
}

\begin{abstract}
Öz
Halkla ilişkiler, temsil ettiği kuruluşların imaj ve itibarının oluşturulması, korunması ve güçlendirilmesi adına hedef kitleleri ile stratejik iletişim süreçlerini yürüten bir iletişim disiplinidir. Ancak başka kurum ve kuruluşların imajı ve itibarı konusunda önemli görev ve sorumluluk üstelenen halkla ilişkilerin, kendi mesleki imaj ve itibarını hak ettiği ölçüde inşa edip koruyamaması ironik bir durum olarak karşımıza çıkmaktadır. Buradan yola çıkılarak yapılan bu çalışmada üniversitelerin önlisans ve lisans halkla ilişkiler ve tanıtım bölümlerinde öğrenim gören öğrencilerin aileleri ve yakın çevrelerinin halkla ilişkiler mesleği üzerine tutum ve algılarının ölçülmesi amaçlanmaktadır. Bugüne kadar yapılan çalışmaların çoğunluğunun meslek profesyonelleri ve akademisyenler ve öğrenciler üzerine yapılmış olması fakat hiç öğrenci yakınlarının görüşlerinin alınmamış olması bu çalışmanın önemini ortaya koymaktadır. Bu amaçla İstanbul Aydın Üniversitesi İletişim Fakültesi ve ABMYO Halkla İlişkiler ve Tanıtım bölümlerinde öğrenim gören öğrencilerin yakınlarına yönelik bir anket çalışması uygulanmış ve toplam 482 kişiye ulaşıımıştır. SPPS 17.0 programı ile yapılan analiz sonucuna göre, ailelerin konuyla ilgili görüşleri çocuklarının bu bölümde okumalarıyla beraber değişmiş ancak mesleğin kapsamını hala tam anlayamamış oldukları görülmüştür.
\end{abstract}

Anahtar Kelimeler: Halkla ilişkiler, halkla ilişkiler meslek algısı, halkla ilişkiler eğitimi, meslekleşme

\section{A Research On Attitudes and Perceptions On Public Relations Profession of The Relatives of Students Who Study Public Relations and Publicity Programs}

\begin{abstract}
Public relations is a communication discipline implementing strategic communication processes with target audiences about constituting, preserving and strengthening of image and reputation of the corporations represented. However, it can be considered an irony that public relations profession, which undertakes significant tasks and responsibilities related to the image and reputation of companies and organizations, cannot preserve the image and reputation of their profession accurately. Accordingly, the purpose of the research was to measure the attitudes and perceptions of the
\end{abstract}

1 Yrd. Doç. Dr., İstanbul Aydın Üniversitesi, İletişim Fakültesi, Reklamcılık Bölümü.

2 Yrd. Doç. Dr., İstanbul Aydın Üniversitesi, İletişim Fakültesi, Halkla Illişkiler ve Tanıtım Bölümü. 
families and close relatives of the students studying in associate degree and bachelor degree programmes of public relations and publicity departments. The significance of the study is based on the fact that majority of the researches carried out so far was related to the perceptions of the professionals and academicians and students; and yet, no opinions of students' relatives have been received. Therefore, a questionnaire was carried out among the relatives of the students who have been studying Istanbul Aydin University Faculty of Communication and Anadolu Bil Vocational School of Higher Education Public Relations and Publicity departments and 482 persons were reached in total. According to the analysis result acquired via SPPS 17.0 program, the opinions of the subject families changed during the students studying period in the related departments; and yet, they have not completely perceived the extent of the profession yet.

Keywords: Public relations, public relations profession perception, public relations education, professionalisation. 


\section{Giriș}

$\mathrm{H}$ alkla İlişkiler bilim dalı, iletişimin birçok dalının yanı sıra pazarlama, psikoloji, sosyoloji, ekonomi, edebiyat gibi birçok disiplin ile ilişki halindedir. Bu kadar çok disiplinden beslenmesi halkla ilişkilerin her geçen gün önemini arttırmakta, eğitimini kapsamlı bir hale getirmektedir. Bununla birlikte artan önemine, yapı ve fonksiyon çeșitliliğine rağmen mesleğin doğru tanımlanması, açıklanması ve yorumlanması noktasında hala çeşitli sorunlar yaşamaktadır. Her ne kadar alanın akademisyenleri ve uygulayıcıları halkla ilişkilerin kapsamının ve işlevinin ne denli önemli olduğunun, her türlü kuruluş için vazgeçilmez bir yönetim fonksiyonu olduğunun altını çizerek vurgulamaya çalışsalar da sadece Türkiye'de değil, uluslararası alanda da kamuoyu açısından halkla ilişkiler bir meslek olarak hak ettiği saygınlığa ulaşmış değildir.

Halkla ilişkilerin hak ettiği değere ulaşamamasının başlıca sebepleri arasında orta ve küçük ölçekli kuruluşların halkla ilişkiler mesleğinin fonksiyonlarını kavrayamamış olması ve sektörde mesleğin icrasında eğitim ve yetkinlik şartlarına sahip nitelikli eleman aranmaması gösterilebilir. Bunların yanı sıra meslek uygulayıcılarını etik kodlar açısından denetleyen herhangi bir mekanizma olmayışı, akreditasyon eksikliği gibi sebepler de meslekleşmenin önünde engel teşkil etmektedir. Öksüz de bu sebepleri toplum tarafından tanınmama, imaj sorunu, profesyonel standartların ve yetkinliklerin belirsizliği, kamu yararı sağlamadığı görüşü, meslek örgütlerine katılımın fazla olmaması ile akreditasyon ve lisanslamanın olmaması gibi faktörler olarak belirtmektedir (Öksüz, 2015: 249).

Kopenhaver (1985) ve Ehling (1992) yaptıkları araştırmalarda halkla ilişkilerin meslek olarak yeterliliğinin tartışılmaz olduğunu ancak bu mesleğin sıklıkla yanlış anlaşıldığını, diğer mesleklere göre halkla ilişkiler disiplinin boyutlarının açık olmadığını ileri sürmektedirler (Kopenhaver, 1985'den ve Ehling, 1992: 455'den aktaran Bowen, 2009: 402-403 ). Cameron, Sallot ve Lariscy'in yaptığı araştırmalar (1998) akademisyen ve uygulayıcıların meslek standartları konusunda hala fikir birliği içinde olmadıklarını ifade ederken (Sallot vd.,1998:14); Bowen (2009:408) yaptığı araştırmalarda halkla ilişkiler mesleği ile ilgili yanlış anlamaların oldukça yaygın olduğunu pazarlama, tanıtım, manipülasyon gibi kavramlarla sıkça karıştırılı̆̆ını ortaya koymaktadır. Bunlar ve benzeri araştırmalar halkla ilişkilerin çeşitli kişi ve gruplar üzerindeki algısının hala sıkıntılı bir süreç yaşadığını göstermektedir.

Yirminci yüzyıl başı itibariyle iş dünyasında varlık göstermeye çalışan halkla ilişkiler bu süreç zarfında sürekli kendini saygın bir meslek olarak kabul ettirme kaygısı içinde olmuştur. Günümüzde de halkla ilişkiler, dünyada ve ülkemizde itibar kazanma ve saygınlık görme mücadelesine devam etmektedir. Bu durum üniversite öğrencisi adaylarının bu bölümü seçmelerinde ve yakınlarına bölümü anlatmalarında zorluk çekmelerine sebep olmaktadır. Ayrıca çevredeki insanların halkla ilişkiler öğrencilerinin okudukları bölüm ve yaptıkları işe yönelik olarak olumsuz tutum ve yargılara sahip olmalarına neden olmaktadır.

Öte yandan toplum genelindeki olumsuz algı ve tutumlara karşın fakültelerin halkla ilişkiler bölümlerinin kontenjanlarının dolması, gençlerin mesleğe olan ilgisinin artması 
sevindirici bir durumdur. Ancak bu durum yine de genel görüşlerin olumluya çevrilmesi konusunda beklenen düzeye gelmesinde yetersiz kalmaktadır. Bu çalışmanın amacı da fakültelerde artan öğrenci oranına karşın öğrenci ailelerinin ve çevrelerinin halkla ilişkiler mesleğine karşı tutum ve algılarının düzeyini ortaya koymaktır.

\section{Halkla Illișkilerin Tanımlanma Sorunu}

Birçok bilim dalı ile işbirliği içinde olan halkla ilişkiler kavramının tanımı üzerinde tam bir görüş birliğine varılamaması kavramın sosyal bilimlerin alt dalları içinde yorumlanmasına sebep olmaktadır.

Yönetime danışmanlık işlevinden imaj yönetimine, kriz iletişiminden pazarlama iletişimi işlevine kadar çok farklı alanlarda uygulanabilen halkla ilişkiler, birlikte düşünüldüğü komşu dallarla ilişkili olduğu kadar aynı zamanda bağımsız bir faaliyet alanı ve iletişim disiplinidir (Peltekoğlu, 2007: 1).

Halkla ilişkilerin tanımı, fonksiyonları ve etiksel boyutu sıkça tartışılagelen konuların başında yer almaktadır. Halkla ilişkiler ile ilgili temel kavram kitapları incelediğinde birçoğunda kavram hakkında birçok tanım verildiği ve son olarak kitap yazarının kendi tanımıyla bölümü bitirdiği görülmektedir (Okay ve Okay, 2007: 2; Peltekoğlu, 2007: 1; Kazancı, 2002: 59; Yenğin, 2004: 7; Erdoğan, 2008: 19; Bülbül, 2004: 9). Bu konuyla ilgili 1976 yılında Rex Harlow tarafından gerçekleştirilen ve 472 farklı halkla ilişkiler tanımının incelenmesi sonucu ortaya çıkan tanım, IPRA (Uluslararası Halkla İlişskiler Derneği) tarafından "iyi bir tanım" olarak değerlendirilmiştir (Sjöberg, 1998:53'den aktaran Pira, 2004: 225). IPRA'ya göre:"Halkla ilişkiler, bir kuruluşla hedef kitlesi arasındaki karşılıklı iletişimi, anlayışı, kabulü ve işbirliğini oluşturmaya ve sürdürmeye yardımcı olan, sorun ve problemlerin yönetimini içeren, kamuoyuna cevap veren, kamuoyunun bilgilendirilmesi için yönetime yardımcı olan, kamu yararına hizmet etmek için yönetimin sorumluluğunu tanımlayan ve vurgulayan, eğilimleri önceden tahmin etmeye yardımcı olmak için bir erken uyarı sistemi gibi hizmette bulunan, değişikliklerden etkin bir biçimde faydalanmak için yönetime yardımcı olan ve başlıca araçları olarak ahlaki iletişim tekniklerini ve araştırmayı kullanan ayrıcalıklı bir yönetim fonksiyonudur" (Hutton, 1999:200'den aktaran Okay ve Okay, 2007: 2). Bu araştırmanın sonucuna göre halkla ilişkiler, uzmanlık gerektiren bir yönetim görevidir.

Yönetimin bir parçası olarak çeşitli gruplar arasında iletişimi düzenler, kamuoyu ve iletişim araştırmaları çerçevesinde hareket eder, hedef kitlenin davranışları hakkında yönetimi bilgilendirir. Halkla ilişkiler ayrıca kuruluşun kar amacı dışında sosyal sorumlulukları da olduğu gerçeği ile hareket eder (Peltekoğlu, 2007: 3). Her geçen gün genişleyen fonksiyonları çerçevesinde halkla ilişkiler, kurumun tanınırlığını, bilinirliğini sağlamak amacını güderken, bu yönde sadece kurumun değil aynı zamanda toplumun çıkarlarını gözetmek ve kamu bilinci oluşturmak durumundadır.

Halkla ilişkiler, etkilemek, anlayış kazanmak, bilgi sağlamak amacıyla planlı ve programlı yapılan araştırma ve analiz içeren düzenli bir çalışmadır. Bir halkla ilişkiler faaliyetinin yapılmasının amacı kolay olmasa da hem kurum için fayda sağlamak hem de kamu yararına hizmet etmektir (Okay ve Okay, 2005: 5). Halkla ilişkilerin bir "iletişim yönetimi” olduğuna vurgu yapan Grunig'e göre de halkla ilişkiler bir örgütle 
o örgütü ilgilendiren kamular arasındaki iletişim yönetimidir. İletişim yönetimi olarak halkla ilişkiler, bir örgütün iç ve dış kamularıyla kurduğu iletişime ait planlama, yürütme ve değerlendirme etkinliklerinin toplamını ifade etmektedir (Grunig, 2005: 15). Benzer şekilde Hutton da halkla ilişkileri "stratejik iletişim yönetimi" olarak tanımlamakta ve halkla ilişkilerin ikna edici, savunucu, eğitici, bilgi tedarikçisi, taraftar, imaj yapıcı, itibar yönetici, ilişki kurucu rolleri olduğunu belirtmektedir. Öncelikli fonksiyonlarını ise; araştırma, imaj oluşturma, danışma, yönetme, ön uyarı, yorumlama, iletişim kurma ve müzakere etmek şeklinde sıralamaktadır (aktaran Vercic vd, 2001).

Halkla ilişkiler kavramı için literatür dahilinde çok sayıda tanımlama yapılmaktadır. Sadece halkla ilişkiler tanımları değil fonksiyonları da yıllar içinde değişmekte, genişlemektedir. Erken dönem yapılan halkla ilişkiler tanımlarında tanıtım ve basın ajanslığı rolleri vurgulanırken, modern tanımlarda ise ilişki inşa etmek, karşılıklı yarar gibi roller ön plana çıkmaktadır. Genel olarak bakıldığında tanımlamalarda karşılıklı iletişim süreci, anlayıș ve güven ortamının yaratılması ve bunun sürdürülmesi, kamuoyunu etkileme ve kuruluş hakkında olumlu imaj yaratılması gibi önemli unsurlar yer aldığı görülmektedir. Tanımlar, halkla ilişkilere yaklaşım açısı, tanımı yapan kişi/ kurumun özellikleri ve tanımda vurgulanması istenilen konularla şekillenmektedir (Okay ve Okay, 2007: 10).

Genel olarak halkla ilişkilerin kamuoyu tarafından tek yönlü ve sadece müşteri ilişkilerinden ibaret olarak algılanması, reklamcılık, insan kaynakları, sekreterlik gibi başka mesleklerle karıştırılması, danışma bürosu, insan kaynakları, müşteri şikayet birimi, karşılama ofisi, organizasyon işleri ofisi șeklinde algılanması halkla ilişkilerin tanımlanma sorunundan kaynaklanmadır. Bunun başlıca sebebi halkla ilişkilerin çok yönlü, multidisipliner ve birçok alanda uygulanabilir iletişim süreçlerini içermesidir. Örneğin pazarlama alanından bakıldığında halkla ilişkiler bütünleşik pazarlama süreci içerisinde ürün/hizmet tutundurma işlevi ile tanımlanırken, insan kaynakları alanından bakıldığında kurumiçi iletişim yönüyle tanımlamalar yapıldığı görülmektedir. Tarihsel gelişimine bakıldığında ise medya ilişkileri ve propaganda çalışmaları ile birlikte ortaya çıkan halkla ilişkiler kavramı, tarihsel dönüşüm sürecinde dönüşerek günümüzde çok yönlü bir iletişim görevi olarak kabul görmeye başlamıştır. Bu tanımlamalar akademik ve profesyonel çevre tarafından bilinmektedir fakat toplum tarafından bu şekilde algılanmamaktadır. Görev tanımında yer alan itibar yönetimi, algı yönetimi gibi işlevlerin aksine halkla ilişkilerin meslek olarak kendini tanımlamakta, kendi itibarını yönetmekte yetersiz kalması derin bir paradoks oluşturmaktadır.

Toplumun halkla ilişkiler algısı uluslararası alanda da araştırma konusu olmuştur. Örneğin, Bowen toplum halkla ilişkilerin bilgi sağlayıcı, problem çözücü, arabulucu, etik danışman, kriz yöneticisi ya da sosyal değişimin kolaylaştırıcısı rolünü biliyor mu sorusunu sormaktadır (Bowen, 2009: 403). Uluslararası alanda halkla ilişkiler ülkemizden farklı olarak manipülasyon, algı yönetimi, spin doctor gibi kavramlarla birlikte anılarak etik açıdan tartışılırken, ülkemizde kamuoyunda hala mesleğin ne olup olmadığı netleşmemiştir. Bu doğrultuda meslekleşme sürecinde kendini tanımlama sorunu ile sürekli karşı karşıya kalan alanın, doğal olarak kamuoyu tarafından doğru tanımlanamaması doğaldır. 
anlaşıldığı sonucuna varmaktadır (Kopenhaver, 1985'den aktaran Bowen, 2009: 402). Bu temel problem çerçevesinde birçok araştırma yapılarak çeşitli gruplar tarafından halkla ilişkilerin nasıl algılandığı ortaya konulmaya çalışıımıştır.

Sonuç olarak halkla ilişkiler basın bürolarının, basın bültenlerinin ötesine çoktan geçmiş durumdadır. Beslendiği farklı disiplinlerin yanı sıra, kamunun ve özel iş dünyasının dönüşüm ekseninde halkla ilişkiler de sürekli bir değişim içindedir. Gerek eğitim müfredatının gerekse görev tanımlarının sosyo-kültürel, teknolojik, siyasi, ekonomik faktörler doğrultusunda adaptasyonu kaçınılmaz bir gerçeklik olmakla beraber üniversitelerin ve danışmanlık ajanslarının bu gelişmeleri yakalayabilmek için çaba gösterdikleri ancak hala yeterli olmadığı görülmektedir.

\section{Halkla Illișkilerin Meslekleșme Sorunu}

Toplumun halkla ilişkileri özellikle bir meslek olarak değerlendirmemesi, bu alanda uzmanlaşmak isteyen kişileri alandan uzaklaştırmakta ve meslek uygulayıcılarının hak ettiği saygınlığı görmemesine neden olmaktadır. Abdullah ve Threadgold yaptıkları araştırmada halkla ilişkiler bir meslek midir sorusundan yola çıkarak halkla ilişkiler için meslekleşmenin dört boyutunu ortaya koymuştur. Bu boyutlar bilgi tabanı ve kişisel yetkinlikler, eğitim ve araştırma, etik kurallar ve akreditasyon ve lisanslamadır. Araştırma sonucunda halkla ilişkilerin hızla büyüyen ve modern bir yönetim disiplini olduğu, ancak henüz tıp, hukuk ve muhasebecilik gibi "gerçek bir meslek" haline gelmediği sonucuna varılmıştır (Abdullah ve Threadgold, 2008: 286). Ehling ise halkla ilişkiler eğitimi ve profesyonelleşme ile ilgili çalışmasında halkla ilişkilerin meslek olarak yeterliliğinin tartışılmaz olduğunu ancak diğer mesleklere göre halkla ilişkiler disiplinin boyutlarının endüstri dışındakiler için açık olmadığını ileri sürmüştür (Ehling, 1992: 455'den aktaran Bowen, 2009: 403).

Evrensel Akreditasyon Kurulu tarafından 2000 yılında gerçekleştirilen çalışmanın devamı olarak yapılan 2010 Halkla İlişkiler Uygulama Analizi, güncel halkla ilişkiler uygulamasında mesleki yetkinlikleri ve çalışma kategorilerini ortaya koymaktadır. Sonuçlar 2010 yılı halkla ilişkiler uygulamaları kapsamındaki bilgi, beceri ve yeteneklerin (mesleki yeterliliklerin), genel iş becerileri, medya ilişkileri ve teorik bilgi üzerine odaklanmış olduğunu göstermektedir (Sha, 2011: 195).

Bir işin meslek olarak kabul edilebilmesi için (Gordon, 1950; Caplow, 1954; Milerson, 1964) toplumsal fayda, uzmanlaşma, meslek eğitimi, meslek etiği ve dernekleşme olmak üzere toplam beş unsura sahip olması gerekmektedir (Grieve, 2005: 8'den aktaran Tuncer, 2011: 64). Halkla ilişkiler bu unsurlar çerçevesinde düşünüldüğünde meslekleşme sürecini tamamlamış gibi gözükse de meslek örgütlerinin yetersizliği, pasifliği ve Türkiye'de akreditasyon zorunluluğu olmaması sebebiyle bu sürecin tamamlandığını söylemek mümkün olmamaktadır. Halkla ilişkiler eğitiminin yaygın olmasına, sektörde uygulama çalışmalarının yoğunluğuna ve 1972 senesinden itibaren mesleğin bir derneği (TÜHID) bulunmasına rağmen günümüzde halkla ilişkiler 'herkesin yapabildiği bir iş' imajından kurtulamamıştır (Öksüz, 2015: 261). 


\section{Halkla Ilișkiler Mesleği Algısı Üzerine Yapılan Araștırmalar}

Literatürde halkla ilişkiler mesleği algısı ile ilgili araştırmalar incelendiğinde öncelikle işletmelerin mesleği nasıl algıladıkları üzerine araştırmalar ilk sırada yer almaktadır. Ülkemizde işletmelerin verdikleri iş ilanlarında halkla ilişkiler mesleğini nasıl sunduğu konusunda gerçekleştirilen araştırmada Hürriyet İnsan Kaynakları Eki'nde bir yıl süre ile yayınlanan ve içinde "halkla ilişkiler" kelimesi geçen iş ilanları incelenmiştir. Araştırma sonuçlarına göre ilanların \%73,08'inde herhangi bir iş tanımı veya kriter verilmediği görülmektedir. İlanların \%49,36'sında eğitim kriteri bulunmadığı görülmüştür. Halkla ilişkiler mesleğinin \%11,54 oranında reklamcılık, \%6,41 oranında pazarlama ile bağdaştırıldığı görülmektedir. Araştırma sonucunda Türkiye'de orta ve küçük ölçekli kurumların halkla ilişkiler mesleğini tek yönlü olarak ele aldıkları, genelde basın ilişkileri ya da müşteri ilişkileri konusunda hizmet beklendiği ortaya çıkmıştır (Akbulut, 2008: 77-80).

Özen ve Kılınç'ın Türkiye'de işletmelerde halkla ilişkiler algısı üzerine yaptığı araştırmasının sonuçlarına göre işletmelerdeki halkla ilişkiler algısı, iletişim ve medya boyutu, bilinirlilik boyutu ve beklenti boyutlarıyla ilişkilidir. İşletmeler tanıtım ve iletişim konularına verdiği önem ile halkla ilişkiler algıları doğru orantılıdır. Çalışmada işletmelerin tanınır olmasının, halkla ilişkilere verilen önem ile beklentiler arasında aracı rol üstlendiği sonucuna ulaşılmış ayrıca işletmelerin iletişim ve medya ile iletişim boyutunun, halkla ilişkilere verilen önem ile beklentiler arasında aracı rol üstlendiği sonucuna ulaşılmıştır (Özen ve Kılınç, 2015: 166). Yine Türkiye'de yaygın olarak kullanılan web sözlüklerinde halkla ilişkiler mesleğinin ve kavramının algılanışı ve temsili ile ilgili yapılan araştırmada halkla ilişkiler mesleğinin farklı meslek alanları ile karıştırıldığı, özellikle sekreterlik ve pazarlama mesleği gibi görüldüğü ortaya çıkmıştır. Bu görüşler doğrultusunda mesleğin bir kadın mesleği olarak görüldüğü de gözlenmektedir (Doğru, 2016: 49).

Yıldırım ve Becan'ın (2017:293) halkla ilişkiler ve tanıtım bölümlerinde öğrenim gören öğrenciler üzerine yaptıkları araştırma ise öğrencilerin bölüm tercihlerini bilinçli olarak yaptıklarını, bölümlerinden pişman olmadıklarını, bölüm değişikliği yapmak istemediklerini ve böyle bir meslek sahibi olmanın kariyerlerine prestij katacağı düşüncesinde olduklarını ortaya koymaktadır. Bu araştırmanın sonucu değerlendirildiğinde gençlerin ilk başta mesleği çok fazla tanımasalar bile bilinçli tercih yaptıklarını ve öğrenim gördükçe daha olumlu bir yaklaşım sergilediklerini göstermektedir.

Uluslararası alanda ise Cameron, Sallot ve Lariscy halkla ilişkilerin meslekleşme standartları ile ilgili yaptığı çalışmada mesleğin akademik ve iş çevrelerinde sekiz ana boyut üstünden tartışılabileceğini ortaya koymuşlardır. Bu boyutlar teknik beceriler, ücret düzeyleri, araştırma yeterliliği, örgütsel konum, etik performans, eğitim, cinsel ve ırksal ayrımcılık, ve akreditasyondur (1996: 56). Bu araştırmayı takiben 1998 yılında aynı ölçeği tekrar uygulayan araştırmacılar, halkla ilişkiler alanında akademisyen ve uygulayıcıların meslek standartları konusunda çok az fikir birliği içerisinde oldukları ortaya koymuştur (Sallot vd.,1998:14).

Bowen, iki yıl süreyle lisans öğrencilerinden oluşan 10 odak grubu ile yaptığı 
araşıırmada halkla ilişkiler mesleği ile ilgili yanlış anlamaların oldukça yaygın olduğunu mesleğin hala pazarlama, tanıtım, imaj oluşturma ve manipülasyon gibi kavramlarla karıştırıldığını ve halkla ilişkilerin sorumluluklarının açık olmadığını ortaya koymuştur (2009: 408).

Güney Kore'de kamu ve özel sektörde çalışan halkla ilişkiler uygulayıcılarının meslek standartlarına yönelik yapılan araştırmada özel sektör uygulayıcılarının halkla ilişkileri daha çok bir reklam ve pazarlama faaliyeti olarak algıladıkları görülmüştür. Kamu çalışanlarının ise halkla ilişkileri kamuoyunu bilgilendirme işlevi gören bir faaliyet olarak algıladıkları ortaya çıkmıştır (Park, 2003: 270).

Stacks, Botan ve Turk yaptıkları araştırmada halkla ilişkiler uygulayıcıları ve eğitimcilerinin halkla ilişkiler konusundaki algıları arasındaki uyuşmazlıkları ortaya koymuştur. "Genel olarak, halk, halkla ilişkilerin ne olduğunu anlıyor" ifadesine, katılımcıların \%24'ü şiddetle karşı çıkmış, \%61'i karşı çıkmış, \%85'i ise halkın zihnindeki halkla ilişkilerin belirsizliği konusunda endişelerini dile getirmiştir (1999: 11). Bu da katılımcıların halkın, halkla ilişkilerin ne olduğunu anlamadığını düşündüklerini ortaya koymaktadır.

\section{Dünyada ve Türkiye’de Halkla Illișkiler Eğitimine İlișkin Çalıșmalar}

Bu çalışmada toplumun bir parçası olarak halkla ilişkiler bölümlerinde öğrenim gören öğrencilerin aile üyelerinin eğitimin öncesi ve sonrasında görüş farklılığının ne oranda değiştiği ölçülmeye çalışılmıştır. Konuyla ilgili olarak yapılan literatür çalışmasında dünyada ve Türkiye'de çoğunlukla sektör çalışanları ve akademisyenler, kısmen de öğrenciler arasında müfredat, meslek eğitimi, ve meslek algısı üzerine çalışmalar yapıldığı izlenmektedir.

Halkla ilişkiler eğitimi, müfredatı ve algısı konusunda; Global Alliance ve PRSA destekli Toth ve Aldoory'nin (2010) çalışmaları, Spacal'ın (2008) Doğu Avrupa ülkelerindeki çalışması, EUPRERA'nın (Avrupa Halkla İlişkiler Eğitim ve Araştırma Derneği) Avrupa genelindeki "European Communication Monitor" $(2007,2009,2011,2016)$ araştırmaları, Fullerton ve McKinnon'ın (2015) PRSA'in öğrenci üyeleri arasında yaptıkları araştırma, Bowen'ın (2003, 2009) Amerikan öğrenciler arasında yaptığı çalışmalar, Gleeson'ın (2013) Avustralya'daki öğrenciler arasında gerçekleştirdiği çalışma, Erzikova and Berger'in (2011) Rus ve Amerikan öğrencilerine karşılaştırmalı olarak yaptığı araştırmaları, Gower and Reber'in (2006) dokuz Amerikan üniversitesindeki öğrenciler arasında yaptığı araştırma, Gallicano and Stansberry'in (2011), Brown, White and Waymer'in (2011) öğrenciler arasında halkla ilişkiler eğitimi ve mesleğine ilişkin tutum ve algılarını ölçtükleri çeşitli araştırmalar mevcuttur.

Yukarıda sayılan araştırmaların sonuçlarında genel olarak öğrencilerin; iş bulma noktasında kaygıları olduğunu, mesleğin etikliği konusunda endişeleri olduğunu ama bu konuya çok önem verdiklerini, öğrencilerin yazma, bilgisayar, etik, sosyal sorumluluk, etkinlik yönetimi gibi konularda kendilerine güvendiklerini ancak iş ve finansal becerilerde eksiklik hissettiklerini, farklı ırklar (beyaz ve siyah) arasında mesleğin kariyer başarısı noktasında farklı düşünceler olmadığını, mesleği tanımlarken halkla ilişkiler ve "tanıtım, pazarlama iletişimi, propaganda" gibi kavramlar arasında karmaşa 
yaşadıklarını, öğrenci gruplarının genellikle mesleği prestijli ve çekici bulduğunu ancak medyanın halkla ilişkilerin imajını olumsuz yansıttığını, halkla ilişkilerin renkli, şov amaçıı yönünün ön plana çıkarıldığını, halkla ilişkiler algısı ile mesleğin beklentileri arasında öğrencilerin kafalarının karışık olduğunu, akademisyenlerine ve meslek profesyonellerinin halkla ilişkilerin ne olduğu konusunda öğrencileri daha iyi bilgilendirmesi gerektiğini ortaya koymaktadır.

Halkla Illişkiler eğitimine ve geleceğine ilişkin diğer çalışmalara bakıldığında EUPRERA (Avrupa Halkla İlişkiler Eğitim ve Araştırma Derneği), Global Alliance, PRSA, Amerikan Halkla İlişkiler Eğitim Komisyonu, IPRA (Uluslararası Halkla İlişkiler Birliği), IABC (Uluslararası İş İletişimcileri Derneği), ICA (Uluslararası İletişim Birliği), AEJMC (Gazetecilik ve Kitle İletişimi Eğitimi Birliği) gibi bir çok kurum ve birliğin araştırması mevcuttur.

Ayrıca konuyla ilgili çok sayıda araştırma yapan araştırmacı ve akademisyenlerden bazılarını Cutlip ve Center (1978), Grunig (1989), Grunig ve Hunt (1984), Kruckeberg (1998), Toth ve Aldoory (1999), Coombs ve Rybacki (1999), L'Etang ve Pieczka (2002), Phyllis ve Len-Rios (2006), Smith ve Navarro (2014), Chappelow (2015), Gonçalves vd.(2013) vb. şeklinde sayabiliriz. Gerek birlik ve derneklerin gerekse bu uzman ve akademisyenlerin yaptıkları çalışmalarda farklı disiplinlerle entegre bir halkla ilişkiler eğitiminin gerekliliğini tekrarlanmaktadır. Bu araştırmalarda genel olarak halka ilişkiler lisans-yüksek lisans eğitim modellerinin ana başlıkları, eğitimde dikkate alınması gereken gelişmeler, ideal halkla ilişkiler eğitimi için kriterler, ders konularının içerikleri, halkla ilişkilerde değişmesi ve gelişmesi gereken içerik ve konular, halkla ilişkiler mesleğinin ve eğitiminin sorunları-çözümleri, müfredatı, akademi ve sektör arasındaki ilişkilerin boyutları, halkla ilişkilerde öne çıkacak ve önem kazanacak konular, mesleğin gerektirdiği kişisel özellikler ve yetkinlikler üzerinde durulmaktadır. Türkiye'de yapılan çalışmalar incelendiğinde ise Yıldırım ve Becan'ın (2017), Güllüpınar'ın (2015), Yazıcı ve Ekinci'nin (2016), Ural'ın (2012) Solmaz vd.'nin, (2009) Canpolat'ın (2013), Vural, Yurdakul ve Başok'un (2004), Okay ve Okay'ın (2008) çalışmaları ön plana çıkmaktadır. $\mathrm{Bu}$ çalışmalarda da halkla ilişkiler eğitimine ve mesleğine yönelik öğrenci algı ve tutumları, halkla ilişkiler eğitiminde önemli olan konuları ve nitelikleri, halkla ilişkiler bölümlerinin eğitim kadroları, müfredatları, öğrencilerin hangi bilgi ve becerilerinin geliştirilmesi gerektiği, etkili bir halkla ilişkiler lisans-yüksek lisans eğitimi için öneriler ele alınmaktadır.

\section{Yöntem}

\subsection{Araștırmanın Amacı ve Önemi}

Halkla ilişkiler, bir meslek olarak ortaya çıkışından itibaren tanınma ve tanımlanma sorunu yaşamaktadır. Halkla ilişkilerin naşı algılandığı üzerine sektör (işveren, meslek uygulayıcıları, ajanslar vb.), akademisyenler veya halkla ilişkiler eğitimi alan öğrenciler gibi birçokgruba yönelikçeşitliaraştırmalaryapılmıştır. Literatürincelendiğinde bu alanda eğitim gören halkla ilişkiler profesyoneli adayı öğrencilerin yakınlarının halkla ilişkileri nasıl algıladığı üzerine ulusal veya uluslararası düzeyde bir çalışmaya rastlanmamıştır. Buradan yola çıkılarak yapılan bu çalışmada üniversitelerin önlisans ve lisans halkla ilişkiler ve tanıtım bölümlerinde öğrenim gören öğrencilerin yakın çevrelerinin halkla 
ilişkiler mesleği üzerine tutum ve algılarının ölçülmesi amaçlanmaktadır. Ayrıca Halkla İlişkiler önlisans ve lisans eğitimi alan öğrenci yakınlarının halkla ilişkiler mesleğine yönelik tutumlarını ve meslek algılarını ölçen, sahaya dayalı çalışmanın olmaması da araştırmanın önemini oluşturmaktadır.

\subsection{Araștırma Soruları}

Çalışmada yukarıda ifade edilen temel amacı gerçekleştirebilmek için şu sorulara yanıt aranmaktadır:

1. Halkla ilişkiler bölümü öğrencilerinin yakınlarının hakla ilişkiler mesleği hakkındaki tutumlarının niteliği nedir?

2. Halkla ilişkiler bölümü öğrencilerinin yakınlarının hakla ilişkiler mesleği ile ilgili algıları nasıldır?

3. Halkla ilişkiler bölümü öğrencilerinin yakınlarının hakla ilişkiler mesleği ile ilgili algıları ile tutumları arasında nasıl bir ilişki vardır?

4. Halkla ilişkiler bölümü öğrencilerinin yakınlarının hakla ilişkiler mesleği ile ilgili algıları, demografik özelliklere, programı tercih etme sırası, nedeni ve mesleği nasıl tanımladıklarına göre anlamlı farklılıklar arz eder mi?

5. Halkla ilişkiler bölümü öğrencilerinin yakınlarının hakla ilişkiler mesleği ile ilgili tutumları demografik özelliklere, programı tercih etme sırası, nedeni ve mesleği nasıl tanımladıklarına göre anlamlı farklılıklar arz eder mi?

\subsection{Araștırmanın Modeli}

Çalışmada öğrencilerin ailelerinin/yakınlarının halkla ilişkiler eğitimine yönelik tutumlarını ve halkla ilişkiler mesleğine yönelik algılarını etkileyen değişkenler ve faktörler tespit edilmeye, tanımlanmaya çalışılmıştır. Dolayısıyla araştırmanın modeli 'keşfedici' ve 'tanımlayıcı' araştırma modelidir.

\subsection{Evren ve Örneklem}

Bu çalışmanın evrenini üniversitelerin İletişim Fakülteleri ve MYO’ların Halkla İlişkiler ve Tanıtım bölümlerinde öğrenim gören öğrencilerin aileleri oluşturmaktadır. Yüksek Öğrenim Kurumu'nun resmi web sitesinde yer alan bilgiye göre 2017 yılı itibariyle Türkiye genelinde, 62 adet İletişim Fakültesi ve fakülteler kapsamında 48 adet Halkla İlişkiler ve Tanıtım Bölümü bulunmaktadır. Ancak bu kitleye ulaşmak ve anketi kontrolü olarak yaptırmak mümkün olmadığından örneklem olarak sadece İstanbul Aydın Üniversitesi'nde İletişim Fakültesi ve ABMYO Halkla İlişkiler ve Tanıtım Bölümlerinde okuyan öğrencilerin ailelerine ulaşılmıştır. Bu kapsamda da anketin cevaplanması aşamasında kontrolü mümkün olamayacağı için mümkün olduğunca dikkatli ve özenli olarak yapacağına inanılan ve gönüllü olarak kabul eden öğrencilere anket formları dağıtılmıştır.

İstanbul Aydın Üniversitesi İletişim Fakültesi ve Meslek Yüksek Okulu "Halkla İlişkiler 
ve Tanıtım Bölümü"nde aktif olarak toplam 354 öğrenci öğrenim görmektedir. 25 Mart 10 Haziran 2017 tarihleri arasında bu öğrencilerden 241 'ine 672 adet anket dağıtılmış, geriye 526 adet anket dönmüştür. Doldurulan anketlerden 44 tanesi geçersiz olması nedeniyle değerlendirme dışı bırakılmış ve 482 adet anket değerlendirmeye alınmıştır.

\subsection{Veri Toplama ve Değerlendirme Yöntemi}

Veri toplama aracı olarak, araştırma modelinin keşfedici ve tarama modeli olması nedeniyle en uygun yöntem olarak anket kullanılmıştır. Türkiye'de ve dünyadaki halkla ilişkiler çalışmaları tarandığında mesleğe ilişkin algı ve tutum konusunda Halkla İlişkiler Bölümlerinde öğrenim gören lisans, yüksek lisans, doktora öğrencilerine, bölümle ilgili akademisyenlere, sektör çalışanlarına yönelik yapılan bir dizi araştırma ile karşılaşılmıştır. Ancak bu çalışmalar kapsamında bu bölümde öğrenim gören öğrencilerin özellikle aileleri ve yakınları arasında onların halkla ilişkiler mesleğine yönelik tutum ve algılarını inceleyen bir çalışmaya rastlanılmamıştır. Bu sebeple hazırlanan anket çalışmasında; Clair'in (1996) meslek tanımlamasını yaptığı makalesinden, Bowen'ın (2003) öğrencilerin halkla ilişkiler meslek algısına yönelik yaptığı araştırmasından, Brown, White ve Waymer'in (2011) öğrencilerin halkla ilişkiler eğitimine başlamadan önce ve eğitim aldıktan sonraki tutumlarını ölçen çalışmasından, White ve Park'ın (2010) Amerika'da halk arasında halkla ilişkiler algısına yönelik yaptığı araştırmasından ve Tsetsura'nın (2011) halkla ilişkilerde cinsiyetçi yaklaşım araştırmasında yer alan ölçeklerden yola çıkılarak bir çalışma hazırlanmıştır.

Ancak bu çalışmalarda kullanılan kavramlar ve önermelerin bazıları birebir Türkçeye çevrildiğinde anlam karmaşası yarattığı ve aileler arasında anlaşııması zor olacağı düşünüldüğü için bunlara benzer ifadeler kullanılması tercih edilmiştir. Sorular hazırlanırken ayrıca öncesinde 8 öğrenci ile derinlemesine mülakat yapılmış, aileleri ve yakınlarının okudukları bölüm ve mesleklerine ilişkin yorum ve düşünceleri sorulmuş, alınan cevaplar değerlendirilmiş, frekans analizi ile en çok tekrarlanan kavramlardan yola çıkılarak çalışmanın soruları desteklenmiştir.

Hazırlanan anket 3 bölümden oluşmaktadır. Anket formunun ilk bölümünde, öğrenci yakınlarının halkla ilişkiler eğitimine yönelik tutumlarını ölçen 22 adet soru, ikinci kısımda ise halkla ilişkiler mesleğinin algısına yönelik 25 adet soru yer almaktadır. Tutum ve algı ölçümü için $5^{\prime}$ li likert ölçek kullanılıp, kesinlikle katılmıyorum (1) - kesinlikle katılıyorum (5) olarak kodlanmıştır. Anketin üçüncü bölümünde ise demografik sorularla birlikte halkla ilişkiler bölümünü neden seçtikleri ve nasıl tanımladıkları sorulmuştur.

\subsection{Araștırmanın Veri Analizi}

Ankette elde edilen veriler, SPSS 17.0 programı kullanılarak analiz edilmiştir. Anketin birinci bölümünde öğrenci yakınlarının, öğrencilerinin halkla ilişkiler eğitimine başlamadan önceki ve başladıktan sonraki mesleğe yönelik tutumlarını tespit etmek için faktör analizi kullanılmıştır. İkinci kısımda da öğrenci yakınlarının, halkla ilişkiler mesleğine yönelik algılarını test edebilmek için faktör analizinden yararlanılmıştır. Anketin üçüncü bölümünde ise Frekans testi aracılığıyla, ankete katılanların demografik özellikleri test edilmiştir. Ayrıca tutum faktörleri ile algı faktörleri arasındaki ilişkiyi ortaya koyabilmek için korelasyon analizinden yararlanılmıştır. Halkla ilişkiler eğitimine 
yönelik tutum ve algılarının öğrenci yakınlarının demografik özelliklerine, program türüne, tercih sırasına, gelir seviyesine, öğrenim durumuna, yakınlık durumuna göre farklılığını belirlemek için de t-Testi, Anova ve korelasyon analizinden yararlanılmıştır.

\subsection{Araștırmanın Sınırlılıkları}

Bu çalışma, evrenin genişliği göz önüne alındığında ve bu evrene ulașmak mümkün olmadığından ayrıca zaman ve bütçenin sınırlıığı nedeniyle sadece İstanbul Aydın Üniversitesi İletişim Fakültesi ve ABMYO Halkla İlişkiler ve Tanıtım Bölümünde öğrenim gören öğrencilerinin yakınları üzerinde yapılmıştır. Ayrıca öğrencilerin yakınlarına birebir ulaşmak mümkün olmadığından anketlerin güvenilir ve gönüllü öğrenciler aracılığıyla gerçekleştirilmesi de çalışmanın bir diğer kısıtııı̆ıdır. Araştırma, 25 Mart 10 Haziran 2017 tarihleri arasında yapılmıştır.

\subsection{Araștırmada Kullanılan Ölçeklerin Güvenilirlik ve Geçerlik Analizi}

Araştırmanın güvenilirliğinin analizi için Cronbach's Alpha (a) katsayısı dikkate alınmıştır. Cronbach's Alpha (a) değeri faktör altındaki soruların toplamdaki güvenilirlik seviyesini göstermektedir. Cronbach's Alpha (a) değerinin 0,70 ve üstü olduğu durumlarda ölçeğin güvenilir olduğu kabul edilir. Ancak, soru sayısı az olduğunda bu sınır 0,60 değeri ve üstü olarak kabul edilir (Durmuş, Yurtkoru ve Çinko, 2011:89).

Çalışmada öncelikle 121 kişiyle bir ön test (pilot çalışma) yapıımıştır. Bu çalışma sonucunda tutum faktörlerinden 5 , algı faktörlerinden 1 soru elenerek, yapılan ön testte elde edilen verilerin güvenilirliği, 0,741 Cronbach's Alpha (a) olarak bulunmuştur. Ancak faktörler tek tek güvenilirlik analizine tabi tutulduğunda yine tutum faktörlerinden 5, algı faktörlerinden 5 adet önerme araştırma kapsamı dışına atılarak, tutumda toplam 12, algıda toplam 19 önerme ile çalışma devam ettirilmiştir.

\subsection{Araștırmada Kullanılan İstatiksel Yöntemler}

Sürekli değişkenleri tanımlamak için deskriptif istatistikler kullanılırken (ortalama, standart sapma, minimum, medyan, maksimum), kategorik değişkenleri tanımlamak için frekanslar (n) ve yüzdeler (\%) kullanılmıştır. Bağımsız ve normal dağılan iki sürekli değişkenin karşılaştırması Student t testi ile bağımsız ve normal dağılıma uygunluk göstermeyen iki değişkenin karşılaştırması Mann Whitney u testi ile yapılmıştır. Normal dağılan iki sürekli değişkenin korelasyonu için Pearson korelasyon analizi, normal dağılıma uygunluk göstermeyen iki sürekli değişkenin korelasyonu için Spearman's rho korelasyon analizi yapılmıştır.

Anketin geçerliliğinin incelenmesi için açıklayıcı faktör analizi yapılmıştır. Açıklayıcı faktör analizinin ön testleri olarak, Bartlett'in küresellik testi ve Kaiser Meyer Olkin'in örnekleme yeterliliğinin ölçümü için kullanılmıştır. Ayrıca örneklem büyüklüğü yeterliliği açısından anti-image correlation matrix de incelenmiştir. Açıklayıcı faktör analizi, Varimax ile Kaiser Normalization Rotation Method ve Temel Bileşenler Analizi kullanılarak gerçekleştirilmiştir. Faktör sayısına karar vermek için Scree plot test, özdeğerlerin 1'den büyük olma kuralı, toplam varyansın açıklayıcılık yüzdesi gibi kriterler kullanılmıştır. 


\subsection{Araștırma Verilerinin Analizi ve Bulgular}

Bu bölümde öncelikle araştırmaya katılan öğrenci yakınlarının demografik özellikleri ile beraber öğrenciye yakınlığı, öğrencinin programı, kaçıncı sınıfta olduğu, bölümü kaçıncı sırada tercih ettiğine ilişkin bilgiler frekans tablosu şeklinde sunulmuştur. Ayrıca öğrencilerinin bu bölümü neden tercih ettikleri ve öğrenci yakınlarının halkla ilişkileri nasıl tanımladıklarına ilişkin veriler de frekans analizi ile aktarılmaktadır.

Tablo 1'de anketi yanıtlayanların \%57,3'nün kadın, \%42,7'sinin erkek olduğu; \%18,5'nin 17-25 yaş grubu, \%21'inin 26-35 yaş grubu, \%27,6'sının 36-45 yaş grubu ve \%33'nün 45 yaş ve üzeri olduğu görülmektedir. Çalışmaya katılan öğrenci yakınlarının eğitimi, \%27,2'si ilköğretim, \%38,2'si lise, \%29,9'u üniversite, \%4,8'i lisansüstü şeklindedir. Anketi yanıtlayanların öğrenciye yakınlığı \%22'si anne, \%16'sı baba, \%17'si abla/ abi, \%44'ü diğer yakınları şeklindeyken, katılımcıların \%44'nün geliri 1001-3000 TL arasında, \%28'nin geliri 3001-5000 TL arasındadır. Anketi yanıtlayanların mesleği \%28'i özel sektör, \%20,1'i ev hanımı, \%12,9'u öğrenci, \%11,6'sı serbest meslek, $\% 10,4$ 'ü emeklidir. Anketi yanıtlayanların öğrencilerinin büyük bir çoğunluğu \%69,5’i 1-5 tercih aralığında bu bölümü tercih ederken, yanıtlayanların öğrencilerinin \%56'ı ön lisans, \%44'ü lisans programında öğrenim görmektedir. Öğrencilerin \%30,1'i 1. Sınıf, \%37,8’i 2. Sınıf, \%14,5’i 3. Sınıf ve \%17,6’sı 4. Sınıf öğrencisidir.

Tablo 1: Öğrenci Yakınlarının Demografik Yapısı

\begin{tabular}{|c|c|c|c|c|c|}
\hline Cinsiyet & Frekans & Yüzde & $\begin{array}{c}\text { Öğrencinin Öğrenim Gördüğü } \\
\text { Program }\end{array}$ & Frekans & Yüzde \\
\hline Kadın & 276 & 57,3 & Önlisans & 270 & 56 \\
\hline Erkek & 206 & 42,7 & Lisans & 212 & 44 \\
\hline Toplam & 482 & 100 & Toplam & 482 & 100 \\
\hline Yaș & Frekans & Yüzde & $\begin{array}{c}\text { Anketi Yanıtlayanın Öğrenciye } \\
\text { Yakınlığı }\end{array}$ & Frekans & Yüzde \\
\hline $17-25$ & 89 & 18,5 & Anne & 106 & 22 \\
\hline $26-35$ & 101 & 21 & Baba & 81 & 16,8 \\
\hline $36-45$ & 133 & 27,6 & Abla/Abi & 82 & 17 \\
\hline 45 ve üzeri & 159 & 33 & Diğer & 213 & 44,2 \\
\hline Toplam & 482 & 100 & Toplam & 482 & 100 \\
\hline Eğitim Durumu & Frekans & Yüzde & Öğrencinin Okuduğu Sınıf & Frekans & Yüzde \\
\hline Ilköğretim & 131 & 27,2 & 1. sınıf & 145 & 30,1 \\
\hline Lise & 184 & 38,2 & 2. sınıf & 182 & 37,8 \\
\hline Üniversite & 144 & 29,9 & $3 . s ı n ı f ~$ & 70 & 14,5 \\
\hline Lisansüstü & 23 & 4,8 & 4. sınıf & 85 & 17,6 \\
\hline Toplam & 482 & 100 & Toplam & 482 & 100 \\
\hline
\end{tabular}




\begin{tabular}{|c|c|c|c|c|c|}
\hline Gelir & Frekans & Yüzde & $\begin{array}{c}\text { Öğrencinin Halkla Ilișkiler } \\
\text { Bölümünü Tercih Sırası }\end{array}$ & Frekans & Yüzde \\
\hline Aylık 1000 TL altında & 92 & 19,1 & $1-5$ & 335 & 69,5 \\
\hline Aylık 1001 - 3000 TL & 212 & 44 & $6-10$ & 77 & 16 \\
\hline Aylık 3001 - 5000 TL & 135 & 28 & $11-15$ & 46 & 9,5 \\
Aylık 5001 - 8000 TL & 26 & 5,4 & $16-20$ & 21 & 4,4 \\
Aylık 8001 TL ve üzeri & 17 & 3,5 & 21 ve üzeri & 3 & 0,6 \\
Toplam & 482 & 100 & Toplam & 482 & 100 \\
Anketi Yanıtlayanın & Frekans & Yüzde & & & \\
Mesleği & 97 & 20,1 & & & \\
Ev hanımı & 56 & 11,6 & & & \\
Serbest meslek & 50 & 10,4 & & \\
Emekli & 135 & 28 & & \\
Özel Sektör & 38 & 7,9 & & \\
Kamu Sektörü & 62 & 12,9 & & \\
Öğrenci & 44 & 9,1 & & \\
Diğer & 482 & 100 & & \\
Toplam & & & & \\
\hline
\end{tabular}

Tablo 2'de öğrencilerin halkla ilişkiler bölümünün neden seçtiklerine dair verilere bakıldığında \%32,4'nün ideali olduğu, \%27,2'sinin üniversite giriş puanının bu bölüme uygun olduğu, \%12,7'sinin iş bulma olanağının çok olduğunu düşündüğü, \%9,5'nin yakın çevresinin önerdiği için bu bölümü seçtikleri görülmektedir.

Tablo 2: Öğrencinin Bölümü Neden Seçtiği Tablosu

\begin{tabular}{|l|c|c|}
\hline Halkla ilișkiler bölümünü çocuğunu/yakınınız hangi nedenle seçti? & Frekans & Yüzde \\
\hline İdeali olduğu için & 156 & 32,4 \\
\hline Yakın çevre önerdiği için & 46 & 9,5 \\
\hline Üniversite giriș puanı bu bölüme uygun olduğu için & 131 & 27,2 \\
\hline İș bulma olanağı çok olduğu için & 61 & 12,7 \\
\hline Kolay bir bölüm olduğunu düșündüğü için & 33 & 6,8 \\
\hline Üniversite diplomasına sahip olmak için & 34 & 7,1 \\
\hline Diğer & 21 & 4,4 \\
\hline Toplam & 482 & 100 \\
\hline
\end{tabular}

Tablo 3'te ise öğrenci yakınlarından halkla ilişkileri tanımlamaları istenmiştir. Anketi 
yanıtlayanların \%52,9'u "Halkla ilişkiler, kuruluş ile halk (hedef kitleleri) arasındaki iletişim süreçlerini yürüten bir yönetim görevidir". ifadesini işaretleyerek en yakın halkla ilişkiler tanımını verdikleri görülmüştür. Ancak halkla ilişkilerin, insan kaynakları, satış ve pazarlama olarak da tanımlandığı görülmektedir.

Tablo 3: Öğrenci Yakınlarının Halkla İlişkiler Tanımı

\begin{tabular}{|l|l|l|}
\hline Halkla ilișkiler Tanımı & Frekans & Yüzde \\
\hline Halkla ilișkiler, kurulușun reklamını yapar. & 43 & 8,9 \\
\hline Halkla ilișkiler, kurulușun medyada haberinin çıkmasını sağlar. & 39 & 8,1 \\
\hline Halkla ilișkiler, satıș ve pazarlamadır. & 69 & 14,3 \\
\hline Halkla ilișkiler, insan kaynakları ile ilgili bir kavramdır. & 60 & 12,4 \\
\hline $\begin{array}{l}\text { Halkla ilișkiler, kuruluș ile halk (hedef kitleleri) arasındaki iletișim süreçlerini } \\
\text { yürüten bir yönetim görevidir. }\end{array}$ & 255 & 52,9 \\
\hline Halkla ilișkiler kuruluș hakkında olumlu propaganda yapan bir birimdir. & 16 & 3,3 \\
\hline Toplam & 482 & 100 \\
\hline
\end{tabular}

Öğrenci yakınlarının halkla ilişkiler mesleğine ilişkin "tutum" faktörlerine yönelik anketin geçerliliğini değerlendirmek için açıklayıcı faktör analizi yapıımıştır. Faktör analizi yapmadan önce bazı ön testler kullanılmıştır. Örneklem yeterliliği için Kaiser-MeyerOlkin (KMO) kriteri incelenmiştir. KMO indeksi, gözlemlenen korelasyon katsayılarını ve kısmi korelasyon katsayılarını karşılaştıran bir indekstir. Bu çalışmada KMO kriteri 0,811 olarak hesaplanmıştır. Bu değer örneklem büyüklüğünün faktör analizi için uygun olduğunu göstermektedir. Bartlett Testi, korelasyon matrisinin köşegen elemanlarının 1 ve köşegende olmayan terimlerin 0 olduğu değerlendirir. Bu test, aynı zamanda, verilerin çoklu normal dağılıma uygunluğunu göstermektedir. Bu çalışmada Bartlett test 0,05 anlamlılık düzeyinde, $\quad \mathrm{p}<0.001$ hesaplandığından popülasyon korelasyon matrisinin birim matris olmadığı söylenebilir. Anti-image korelasyon matrisinin köşegen değerleri 0,666 ile 0,899 arasında değişmektedir. Bu aralık, örneklem boyutunun faktör analizi için uygun olduğunu gösterir.

Faktörlerin yapısını belirlemek için "Temel Bileşenler Analizi” kullanılmış, öğrenci yakınlarının halkla ilişkiler mesleğine yönelik tutumları ölçeği için özdeğeri 1'den büyük 3 faktör elde edilmiştir. Bu faktörler 'Olumsuz Tutum', 'Olumlu Tutum' ve 'Ön Bilgisizlik' şeklinde adlandırılmakla birlikte açıklanan toplam varyanslar Tablo 4'te belirtilmiştir. Bu çalışmada 3 faktör toplam varyansın \%55,9'unu açıklamaktadır. 
Tablo 4: Tutum Faktör Analiz Tablosu

\begin{tabular}{|c|c|c|c|c|c|}
\hline & Tutum Kısmı Faktör Analizi Tablosu & \begin{tabular}{c|}
$\begin{array}{c}\text { Olumsuz } \\
\text { Tutum }\end{array}$ \\
\end{tabular} & $\begin{array}{c}\text { Olumlu } \\
\text { Tutum }\end{array}$ & $\begin{array}{c}\text { Ön } \\
\text { Bilgisizlik }\end{array}$ & $\begin{array}{c}\text { Chronbach } \\
\text { Alpha }\end{array}$ \\
\hline 14 & $\begin{array}{l}\text { Bölüm tercihlerini yaparken çocuğumun/yakınımın bu bölümü seçme kararımı } \\
\text { destekledim. }\end{array}$ & 0,808 & $-0,07$ & $-0,084$ & \\
\hline 13 & $\begin{array}{l}\text { Çocuğumun/yakınımın halkla ilişkiler eğitimi almasından dolayı gurur } \\
\text { duyuyorum. }\end{array}$ & 0,764 & $-0,254$ & 0,034 & \\
\hline 17 & $\begin{array}{l}\text { Çocuğumun/ yakımımın bu bölümden mezun olduktan sonra kolaylikla iş } \\
\text { bulabileceğine inanıyorum. }\end{array}$ & 0,673 & $-0,074$ & 0,061 & \\
\hline 15 & $\begin{array}{l}\text { Çocuğumun/yakınmmı halkla ilişkiler bölümünde okuduğunu söyleyince } \\
\text { çevremden olumlu tepki alırm. }\end{array}$ & 0,621 & $-0,148$ & $-0,14$ & \\
\hline 9 & Halkla ilişkiler mesleği profesyonel eğitim gerektiren bir meslektir. & 0,6 & $-0,072$ & $-0,014$ & \\
\hline 16 & $\begin{array}{l}\text { Halkla ilişkiler eğitimi çocuğumun/ yakınımın sosyal ve entelektïel gelişimine } \\
\text { katkı sağlar. }\end{array}$ & 0,495 & $-0,432$ & 0,013 & 0,639 \\
\hline 12 & Çocuğum/yakınım halkla ilişkiler bölümünde okuduğunu söylemekten çekinir. & $-0,106$ & 0,834 & $-0,032$ & \multirow{4}{*}{0,779} \\
\hline 6 & Halkla ilişkiler mesleğinin ne yaptı̆̆ı anlamakta zorlanırım. & $-0,129$ & 0,58 & 0,394 & \\
\hline 3 & $\begin{array}{l}\text { Çocuğum/yakınım bu bölümde okumaya başlamadan önce halkla ilişkiler alanı } \\
\text { hakkında olumsuz düşüncelerim vardı. }\end{array}$ & $-0,105$ & 0,55 & 0,517 & \\
\hline 11 & Çocuğum/yakınım halkla ilişkiler bölümünde eğitim aldığııı gururla anlatır. & 0,415 & $-0,538$ & 0,188 & \\
\hline 1 & $\begin{array}{l}\text { Çocuğum/yakınım halkla ilişkiler eğitimine başlamadan önce halkla ilişkiler } \\
\text { mesleği hakkında bilgi sahibi değildim. }\end{array}$ & $-0,045$ & 0,097 & 0,846 & \multirow{2}{*}{0,723} \\
\hline 2 & $\begin{array}{l}\text { Çocuğum/yakınım halkla ilişkiler eğitimine başladıktan sonra halkla ilişkiler } \\
\text { mesleği hakkında bilgi sahibi oldum. }\end{array}$ & 0,043 & $-0,085$ & 0,829 & \\
\hline \multicolumn{6}{|c|}{ Extraction Method: Principal Component Analysis. } \\
\hline
\end{tabular}

Öğrenci yakınlarının halkla ilişkiler mesleğine ilişkin "algı" faktörlerine yönelik anketin geçerliliğini değerlendirmek için açıklayıcı faktör analizi yapılmıştır. Örneklem yeterliliği için Kaiser-Meyer-Olkin (KMO) kriteri incelenmiş, KMO kriteri 0,874 olarak hesaplanmıştır. Örneklem büyüklüğünün faktör analizi için uygun olduğunu gösterir. Anti-image korelasyon matrisinin köşegen değerleri 0,647 ile 0,940 arasında değişmektedir. Bu aralık, örneklem boyutunun faktör analizi için uygun olduğunu gösterir.

Faktörlerin yapısını belirlemek için "Temel Bileşenler Analizi” kullanılmış, öğrenci yakınlarının halkla ilişkiler mesleğine yönelik algıları ölçeği için özdeğeri 1'den büyük 4 faktör elde edilmiştir. Bu faktörler 'Basitlik ve Düşük Saygınlık', 'Yüksek Saygınlık ve Güvenilirlik', 'Beceri ve Nitelik' ve 'Etik' şeklinde adlandırılmakla birlikte açıklanan toplam varyanslar Tablo 5 'te belirtilmiştir. Bu çalışmada 4 faktör toplam varyansın $\% 58,8$ 'ini açıklamaktadır. 
Tablo 5: Algı Faktör Yükleri Analiz Tablosu

\begin{tabular}{|c|c|c|c|c|c|c|}
\hline \multicolumn{2}{|r|}{ Algı Faktör Yükleri Analizi } & \begin{tabular}{|c|} 
Basitlik \\
ve Düşük \\
Saygınlık \\
\end{tabular} & \begin{tabular}{c|} 
Yüksek \\
Saygınlık ve \\
Güvenilirlik \\
\end{tabular} & $\begin{array}{c}\text { Beceri ve } \\
\text { Nitelik }\end{array}$ & Etik & $\begin{array}{l}\text { Cronbach's } \\
\text { Alpha }\end{array}$ \\
\hline Alg 1 & Halkla iliş kiler sekreter, danışma gibi bir meslektir. & 0,799 & $-0,167$ & $-0,078$ & $-0,02$ & \multirow[b]{7}{*}{0,860} \\
\hline$A \lg _{1} 2$ & Halkla iliş kiler basit bir meslektir. & 0,794 & $-0,204$ & $-0,167$ & 0,024 & \\
\hline Alg 13 & Bu mesleği yapmak için üniversite diplomasına gerek yoktur. & 0,749 & $-0,193$ & $-0,163$ & 0,122 & \\
\hline $\mathrm{Alg}_{1} 4$ & Halkla iliş kiler geçici bir meslektir. & 0,72 & $-0,093$ & $-0,128$ & 0,246 & \\
\hline $\operatorname{Alg}_{1} 5$ & Halkla iliş kiler mes leği herkesin yapabileceği bir meslektir. & 0,656 & $-0,082$ & $-0,08$ & 0,159 & \\
\hline Alg 16 & $\begin{array}{l}\text { Halkla iliş kiler güzel kadın ve yakışıkl erkeklerin yapabileceği } \\
\text { bir meslektir. }\end{array}$ & 0,608 & $-0,037$ & $-0,114$ & 0,119 & \\
\hline $\operatorname{Alg}_{1} 7$ & Halkla iliş kiler bedava reklam yapar. & 0,563 & $-0,068$ & $-0,06$ & 0,36 & \\
\hline$A \lg _{1} 8$ & Halkla iliş kiler saygın bir meslektir. & $-0,095$ & 0,772 & 0,073 & $-0,084$ & \multirow[b]{6}{*}{0,786} \\
\hline Alg 19 & Halkla iliş kiler etik bir mes lektir. & 0,07 & 0,716 & 0,095 & $-0,343$ & \\
\hline Alg 10 & $\begin{array}{l}\text { Halkla iliş kiler alanında mezuniyet sonrası iş olanaklan } \\
\text { fazladır. }\end{array}$ & $-0,267$ & 0,67 & 0,026 & 0,092 & \\
\hline Algi 11 & $\begin{array}{l}\text { Halkla ilişkiler çağa uyum sağlayan ve sürekli gelişen bir } \\
\text { meslektir. }\end{array}$ & $-0,274$ & 0,665 & 0,205 & $-0,165$ & \\
\hline Alg 12 & İyi bir halkla iliş kiler uzmanının genel kültürü yüksektir. & $-0,122$ & 0,613 & 0,241 & $-0,126$ & \\
\hline $\operatorname{Alg}_{1} 13$ & Halkla iliş kiler mesleği yapanlar güvenilir ins anlardır. & $-0,068$ & 0,571 & 0,027 & 0,003 & \\
\hline $\operatorname{Alg}_{1} 14$ & $\begin{array}{l}\text { Halkla iliş kiler mes leği iletişim becerileri gerektiren bir } \\
\text { meslektir. }\end{array}$ & $-0,169$ & 0,125 & 0,834 & $-0,115$ & \multirow[b]{4}{*}{0,817} \\
\hline Alg 15 & $\begin{array}{l}\text { Halkla iliş kiler becerisi organizas yon yeteneği gerektiren bir } \\
\text { meslektir. }\end{array}$ & $-0,21$ & 0,155 & 0,821 & $-0,051$ & \\
\hline Alg1 16 & $\begin{array}{l}\text { Halkla iliş kiler uzmanlan kendilerini iyi ifade etmek } \\
\text { zorundadır. }\end{array}$ & $-0,139$ & 0,108 & 0,759 & $-0,189$ & \\
\hline Algi 17 & Halkla iliş kiler yabancı dil bilgisi gerektiren bir meslektir. & $-0,058$ & 0,092 & 0,707 & 0,117 & \\
\hline $\operatorname{Alg}_{1} 18$ & Halkla iliş kiler uzmanlan etik davranışlar sergilemez. & 0,248 & $-0,158$ & $-0,062$ & 0,816 & \multirow[b]{2}{*}{0.715} \\
\hline Alg 19 & Halkla iliş kiler sadece bir göz boyamadır. & 0,372 & $-0,174$ & $-0,086$ & 0,683 & \\
\hline
\end{tabular}

Extraction Method: Principal Component Analysis.

Rotation Method: Varimax with Kaiser Normalization

a. Rotation converged in 5 iterations.

Tablo 6 tutum ve algı faktörleri arasındaki korelasyonu ifade etmektedir. Bu tabloya göre bir öğrenci yakınının halkla ilişkiler mesleği hakkında ön bilgi sahibi olmasıyla olumlu tutum geliştirmesi arasında bir ilişki yoktur. Anketi yanıtlayanların olumlu tutumları arttıkça olumsuz tutumları azalmaktadır. Olumsuz tutum ve saygınlık faktörleri arasında anlamlı ve negatif yönde ilişki vardır.

Halkla ilişkiler mesleği hakkında saygınlık boyutunda algı yükseldikçe mesleğe karşı olumsuz tutum azalmaktadır. Kişilerin olumlu tutumları arttıkça basit ve düşük saygınlık görüşü azalmaktadır. Tutum olumluya döndükçe halkla ilişkiler mesleğine yönelik saygınılık da artmaktadır. Bu da iki faktör arasında pozitif ve anlamlı bir ilişki olduğunu göstermektedir. Halkla ilişkilerin beceriklilik ve nitelik gerektirdiğine inanan insanlar mesleğe karşı olumlu tutum sergilemektedir. Halkla ilişkiler mesleğinin etik olmadığına inanan insanların tutumu da olumsuzlaşmaktadır. Anketi yanıtlayanların halkla ilişkiler mesleği hakkında ön bilgisi artıkça tutumları olumlu yönde seyretmektedir. Ön bilgi sahibi olanlar halkla ilişkiler mesleğinin daha etik olduğunu düşünürken bilmeyenler 
halkla ilişkilerin daha çok göz boyama olduğunu, beceri ve nitelik gerektirmediğini düşünmektedir. Dolayısıyla tutumları da olumsuz olmaktadır.

Tablo 6: Tutum ve Algı Faktörleri Arasında Korelasyon Analizi

\begin{tabular}{|l|c|c|c|c|c|c|c|c|}
\hline Variables & Mean & SD & 1 & 2 & 3 & 4 & 5 & 6 \\
\hline 1. Olumlu tutum & 3,6463 & 0,746 & 1 & & & & & \\
\hline 2. Önbilgisizlik & 3,3278 & 1,112 & $-0,029$ & 1 & & & & \\
\hline 3. Olumsuz tutum & 2,3911 & 0,808 & $-0,47$ & 0,234 & 1 & & & \\
\hline $\begin{array}{l}\text { 4. Basitlik ve Düșük } \\
\text { Saygınlık }\end{array}$ & 2,3234 & 0,851 & $-0,401$ & 0,047 & 0,455 & 1 & & \\
\hline $\begin{array}{l}\text { 5. Yüksek Saygınlık ve } \\
\text { Güvenirlik }\end{array}$ & 3,7299 & 0,636 & 0,534 & 0,06 & $-0,319$ & $-0,375$ & 1 & \\
\hline 6. Beceri ve Nitelik & 4,1509 & 0,776 & 0,326 & 0,034 & $-0,201$ & $-0,354$ & 0,33 & 1 \\
\hline 7. Etik & 2,2765 & 1,005 & $-0,279$ & 0,11 & 0,366 & 0,513 & $-0,375$ & $-0,242$ \\
\hline
\end{tabular}

Tanımlayıcı istatistikler yönünden bakıldığında Kurtosis değerleri incelenmiştir. Kurtosis -+2 den küçük olduğu için veriler normal dağılmıştır denilebilir.

Fark analizleri ( $T$ testi) uygulandığında cinsiyet boyutuna bakıldığında olumlu tutum ve etik boyutlarında cinsiyete göre anlamlı farklılıklar bulunmuştur. Olumlu tutum faktörü açısından kadınların erkeklere göre halkla ilişkiler mesleğine tutumlarının daha olumlu olduğu sonucuna ulaşıımıştır $(p=0.039)$. Etik faktörü açısından ise yine kadınların halkla ilişkiler mesleğini daha etik, erkeklerin ise daha etik dışı bulduğu sonucu ortaya çıkmıştır $(p=0.013)$. Diğer faktörler arasında cinsiyet anlamlı bir farklılık oluşturmamıştır.

Halkla ilişkiler öğrencilerinin okuduğu programlar açısından bakıldığında önlisans ve lisans programında okuyan öğrenci yakınlarının tutum ve algıları arasında anlamlı bir farklılık vardır. Lisans programında okuyan öğrenci yakınlarının önlisans programında okuyan öğrenci yakınlarına göre mesleğe karşı daha olumlu tutumları olduğu ortaya çıkmıştır $(p=0.00)$. Lisans programında okuyan öğrenci yakınları halkla ilişkiler mesleğini saygın ve güvenilir bulurken $(p=0.015)$, önlisans programında okuyan öğrenci yakınlarının mesleği daha basit ve düşük saygınlık boyutunda algıladığı ortaya çıkmıştır $(p=0.047)$. Diğer faktörler arasında öğrenim görülen program açısından anlamlı bir farklılık oluşmamıştır.

Anova testi sonuçlarına göre halkla ilişkiler ve tanıtım bölümünde okuyan öğrencinin kaçıncı sınıfta okumakta olduğu, olumlu tutum ve önbilgisizlik değişkenleri anlamlı fark yaratmıştır. 4. ve 2. Sınıflar arasında ve 3. ve 4. Sınıflar arasında farklılıklar 
görülmektedir. Diğer boyutlar açısından ise anlamlı bir fark yaratmamıştır.

Öğrencinin bölümü tercih sırası ile önbilgisizlik ( $p=013)$, yüksek saygınlık ve güvenirlik $(p=, 001)$, beceri ve nitelik $(p=, 001)$ ve etik $(p=0,22)$ değişkenleri arasında farklılık görülmektedir.

Öğrenci yakınlarının yaş faktörü ise herhangi bir değişken için anlamlı bir farklılığa yol açmamaktadır.

Öğrenci yakınlarının eğitim durumu gruplarına göre beceri ve nitelik ile olumlu tutum değişkenleri farklılık göstermemektedir. Buna karşılık önbilgisizlik $(p=, 000)$, yüksek saygınlık ve güvenirlilik $(p=, 002)$, etik $(p=, 001)$, olumsuz tutum $(p=, 001)$ ve basitlik ve düşük saygınlık $(p=, 001)$ değişkenleri eğitim durumuna göre anlamlı farklıık göstermektedir.

Öğrenci yakınlarının gelir durumuna göre yüksek saygınlık ve güvenirlilik $(p=, 002)$ ve olumlu tutum $(p=, 030)$ değişkenleri anlamlı farklılıklar göstermektedir. Öğrenciye yakınlık durumu ise sadece yüksek saygınlık ve güvenirlilik $(p=, 008)$ değişkeni için anlamlı farklııı göstermektedir. Bunun dışındaki herhangi bir değişken için anlamlı bir farklılığa yol açmamaktadır.

Öğrenci yakınlarının meslek gruplarına göre bakıldığında ise olumlu tutum $(p=, 025)$, olumsuz tutum $(p=, 044)$ ve basit ve düşük saygınlık $(p=, 001)$ değişkenlerine göre anlamlı farklılık olduğu görülmektedir.

\section{Sonuc}

Gerek yurt içinde gerek yurt dışında hakkında sayısız kitap, makale yazılmasına, araştırmalar yapılmasına, üniversitelerde ilgili bölümlerin neredeyse tamamına yakın kontenjanlarının dolmasına rağmen hala tanımlanma, anlaşılma ve saygınlık sorunu yaşayan kaç meslek vardır? Üstelik de temel sorumluluk alanı ve görev tanımı, adına çalıştığı kişi veya kurumların hedef kitleleri karşısında tanınırlığını-bilinirliğini artırmak, itibarını ve saygınlığını inşa etmek, karşılıklı olarak iletişim süreçlerini yönetmek olarak ifade edilirken. İşte halkla ilişkiler böylesine talihsiz bir meslek olarak karşımıza çıkmaktadır.

Neredeyse yüzyıldır profesyonel olarak hayata geçmesine, yurt dışında ve içinde dernekleşmesine, danışman şirket sayısı ve kurum içi departman sayısı anlamında artmasına, birçok üniversitede yüksek puanlarla binlerce öğrenci almasına rağmen halkla ilişkiler mesleği toplumun zihnindeki olumsuz algıları kıramamaktadır.

Multidisipliner yapısıyla halkla ilişkilerin görev ve sorumluluklarının kapsamı her geçen gün genişlemektedir. Örneğin European Communication Monitor 2011 ve 2016'daki raporuna göre halkla ilişkilerden beklentiler; dijital gelişmeler ve sosyal medyanın yönetimi, güven inşası, hedef kitlelerle interaktif ve şeffaf iletişim ortamları oluşumu, iletişim koçluğu, uluslararası iletişim, iletişimde büyük verinin kullanımı, üst yönetime koçluk, stratejik iletişim kurgusu, kişisel koçluk gibi çok önemli ve kritik görevler olarak 
sıralanmaktadır. Raporda belirtilen, böylesine önemli sorumlulukları yerine getirebilecek halkla ilişkiler profesyonellerinin taşıması gereken niteliklerden bazıları ise: yaşam boyu öğrenmeye istekli, bireysel ve kültürel farklılıklara karşı duyarlı, meraklı, etik kurallara uyan, problem çözücü, proje yönetebilen, stratejik planlama yapabilen, data analizi yapabilen, araştırma biçimlerine hakim, geleneksel-dijital medyayı kullanabilen, iyi yazı yazabilen, ikna kabiliyeti yüksek, en yeni teknolojileri takip edip hakim olan, iletişim ve halkla ilişkiler teori ve pratiklerini bilen, farklı disiplinlerle kendini geliştiren bireyler olarak sıralanmaktadır.

Yukarıda belirtilen sorumluluk ve yetkinlikler, hiç de küçümsenecek tanımlamalar ve nitelikler olmamasına rağmen halkla ilişkiler, toplum ve medya nezdindeki olumsuz yargılardan kurtulamamaktadır. Bu olumsuz algı sadece Türkiye'de değil, European Communication Monitor 2011 raporunun da gösterdiği üzere Avrupa ve dünyanın geri kalanında da benzer durumdadır. Rapor sonuçlarına göre İngiltere ve Polonya başta olmak üzere Avrupa'nın genelinde medyada halkla ilişkilerin olumsuz bir imajı bulunmaktadır.

Halkla ilişkilerin hak ettiği değere kavuşamamasının ve farklı mesleklerle karıştırılmasının nedenleri özellikle orta ve küçük ölçekli kuruluşların halkla ilişkiler mesleğinin fonksiyonlarını kavrayamamış olması ve mesleğin icrasında eğitim ve yetkinlik şartlarına sahip nitelikli eleman aranmaması, herkesin yapabileceği bir meslek olarak görülmesi, etik kodları denetleyen herhangi bir mekanizmanın olmayışı, akreditasyon eksikliği şeklinde sıralanmaktadır. Elbette ki bunların yanı sıra medyada ve toplum ağzında halkla ilişkilerin aşağılayıcı, ahlak dışı, yetersiz, basit söylemlerle ifade edilmesi de halkla ilişkilerin saygınlık katsayısını aşağılara çekmektedir.

Bu sonuçlardan yola çıkılarak toplumun parçasını oluşturan öğrenci yakınlarının halkla ilişkiler mesleğine karşı düşüncelerini öğrenmek araştırma alanı olarak başat bir konu haline gelmiştir. Bugüne kadar araştırma konusu olarak ele alınmamış halkla ilişkiler bölüm öğrencilerinin birebir yakınlarının düşünceleri, toplumunun birçok kesiminin tutum ve algısından daha fazla önem arz etmektedir. Çünkü onlar bu mesleğin eğitimini alan öğrencilerin aileleri ve yakınları olarak bu eğitim ve mesleğe karşı nasıl bir tutum sergilemektedirler, çocuklarının bu eğitimi almaları olumlu/olumsuz olarak görüşlerini nasıl değiştirdi, mesleği nasıl tanımlıyor ve anlatabiliyor sorularının cevaplarını bulmak bu araştırmanın parametrelerini oluşturmaktadır.

Bu doğrultuda hazırlanan bir anket formu ile İstanbul Aydın Üniversitesi İletişim Fakültesi ve Anadolu Bil Meslek Yüksek Okulu Halkla Ilişkiler ve Tanıtım bölümlerinde öğrenim gören öğrencilerin ailelerine ulaşılmıştır. Anket sorularının çerçevesi literatürdeki çeşitli çalışmaların yanı sıra öğrencilerle yapılan derinlemesine mülakatlar aracılığıyla çizilmiştir.

Üç bölümden oluşan ankete cevap veren ve değerlendirmeye alınan 482 kişinin yarıdan fazlasının kadın olduğu, büyük kesiminin 36 yaş ve üzerinde olduğu, yarıdan fazlasının lise ve üniversite mezunu olduğu, yanıtlayanlarının yaklaşık yarısının anne/ baba/kardeş diğer yarısının akrabalarının olduğu görülürken, anketi yanıtlayanların öğrencilerinin büyük bir çoğunluğunun bu bölümü ilk beş sırada tercih ettiği, yanıtlayanların öğrencilerinin yarıdan fazlasının lisans programında öğrenim gördüğü 
tespit edilmiştir. Öğrencilerin büyük bir çoğunluğu bu bölüme idealleri olduğu için girmekle beraber, dörtte birinin üniversite giriş puanının bu bölüme uygun olduğu için tercih etmesi bizim üniversiteye giriş sistemimizin bir çıkmazı olarak görülebilir.

Öğrenci yakınlarından halkla ilişkileri tanımlamaları istenmiş ve büyük çoğunluğun mesleği doğru tanımladığı ancak halkla ilişkilerin insan kaynakları, satış ve pazarlama olarak da karıştırıldığı görülmüştür. Birinci ve ikinci araştırma sorusunun yanıtı olarak, literatürdeki diğer araştırmaların ve beklentinin aksine öğrenci yakınlarının halkla ilişkiler mesleğine karşı olan tutum ve algıları genel anlamda olumlu olarak karşımıza çıkmaktadır. Anketi yanıtlayanların halkla ilişkiler mesleği hakkında ön bilgisi arttıkça tutumları olumlu yönde seyrettiği görülmektedir. Öğrenci yakınlarının hakla ilişkiler mesleği ile ilgili algıları ile tutumları arasında nasıl bir iliş̧i olduğunu soran üçüncü sorunun cevabı olarak ise; tutum olumluya döndükçe halkla ilişkiler mesleğine yönelik saygınlık da artmaktadır. Bu da iki faktör arasında pozitif ve anlamlı bir ilişki olduğunu göstermektedir. Öte yandan meslekle ilgili, olumsuz tutum ve saygınlık faktörleri arasında anlamlı ve negatif yönde ilişki vardır. Bu da halkla ilişkiler mesleği hakkında saygınlık boyutunda algı yükseldikçe mesleğe karşı olumsuz tutumun azaldığını ifade etmektedir. Meslekle ilgili ön bilgi sahibi olanlar halkla ilişkiler mesleğinin daha etik olduğunu düşünürken bilmeyenler halkla ilişkilerin daha çok göz boyama olduğunu, beceri ve nitelik gerektirmediğini düşünmektedir.

Dördüncü ve beşinci araştırma sorularının cevapları olarak fark testlerinde cinsiyet boyutuna bakıldığında olumlu tutum ve etik boyutlarında cinsiyete göre anlamlı farklılıklar bulunmuştur. Olumlu tutum faktörü açısından kadınların erkeklere göre halkla ilişkiler mesleğine tutumlarının daha olumlu ve etik faktörü açısından ise yine kadınların halkla ilişkiler mesleğini erkeklere göre daha etik bulduğu sonucuna ulaşılmıştır.

Önlisans ve lisans programında okuyan öğrenci yakınlarının tutum ve algıları arasında anlamlı bir farklılık bulunmaktadır. Lisans programında okuyan öğrenci yakınlarının mesleğe karşı daha olumlu tutumları olduğu, halkla ilişkiler mesleğini saygın ve güvenilir buldukları görülürken, önlisans programında okuyan öğrenci yakınlarının mesleğe karşı daha olumsuz tutum takındıkları, mesleği daha basit ve düşük saygınlık boyutunda algıladığı ortaya çıkmıştır.

Son sınıflarda öğrenim gören öğrencilerin yakınlarında olumlu görüşler daha belirginken, ilk sıralarda tercih edenlerin mesleğe karşı saygınlık, güvenilirlik algıları daha yüksektir. Gelir seviyesi ve eğitimi yüksek olanlar mesleği daha saygın ve güvenilir bulmaktadır.

Araştırma bulguları düşünülenin aksine olumsuz bir tutum ve algı tablosu çizmemektedir. Bu da öğrencilerle birlikte mesleğin daha yakından tanındığı, yıllar içinde düşüncelerin daha olumluya döndüğü, mesleği tanıdıkça, bilgi sahibi oldukça olumsuz tutumun azaldığını göstermektedir.

Bu araştırmanın sonucunun halkla ilişkiler mesleğinin bilinirliği ve tanınırlığı konusunda umut verici bir çalışma olduğu söylenebilir. Ancak maalesef genel anlamdaki tutum ve algıda hala bir sorun olduğu bilinmektedir. Toplum genelindeki olumsuz 
tutum ve algıyı yıkmak için üniversitelerin sürekli değişen ve gelişen müfredatlar doğrultusunda halka ilişkileri öğrencilere doğru anlatması önemlidir. Öte yandan üniversite-sektör işbirliklerinin artırılması, meslek derneklerinin etik uygulamalar ve akreditasyon konusunda daha ciddi çalışmaları gerçekleştirmesi kayda değer adımlar olacaktır. Ayrıca özellikle küçük ve büyük işletmelerle meslek odaları, ticaret odaları aracılığıyla birebir görüşmeler, toplantılar yapılarak bilgilendirmelerin yapılması faydalı olabilir. Halkla ilişkiler danışman şirketlerinin özellikle medya karşısındaki tutum ve davranışlarının düzeltilmesi için birlik ve dernekler aracılığıyla kurallar oluşturulabilir.

Türkiye Halkla İlişkiler Derneği üyelik koşulları yeniden değerlendirilmelidir. Üye sayısı hızla arttırılmalı görev ve sorumluluk alanları genişletilmelidir. Üye sayısının arttırılması için neler yapılabileceği tartışılmalıdır. Ayrıca TOBB ve ITO bünyesindeki mesleğin tanınması için yapılan faaliyetler kamuoyu bilgisine sunulmalı, destek istenmelidir.

Üniversiteler önderliğinde yöneticilere yönelik, halkla ilişkiler mesleğinin örgüt organizasyonlarında olması gereken yeri anlatmak amacıyla seminerler düzenlenmelidir. Bu seminerlerde halkla iliş̧ilerin ikili ilişkiler ya da basın ilişkilerinden ibaret olmadığı vurgulanmalıdır. Ayrıca üniversitelerde verilen halkla ilişkiler eğitimöğretimi kalitesinin özel sektöre uygunluğu analiz edilmeli ve öneriler üretilmelidir.

Ülkemizde halkla ilişkiler sektörü, gelişimine hızlı bir şekilde devam etmektedir. Küreselleşen dünyada yer almak için Amerika'daki ve Avrupa'daki gelişmeler yakından takip edilmektedir. Türkiye'de halkla iliş̧ilerin, profesyonel ve etik ilkelere oturtulması, hem halkla ilişkilerin hem de kurumların iletişim stratejileri oluşturması açısından öncelikli hedef olmaktadır.

Son olarak Türkiye genelinde bu bölümde okuyan öğrencilerle öğrenci yakınlarına ulaşmak gerektiği için birebir ilişkiye geçmek mümkün olmadığından bu çalışma sadece İstanbul Aydın Üniversitesi ile sınırlı tutulmuştur. Ancak bu çalışmanın farklı araştırmacılar tarafından farklı bölgelerde farklı öğrenci yakınlarıyla tekrarlanması çalışmanın kapsamının genişletilebilmesi önemli olacaktır.

\section{Kaynakça}

Abdullah, Zulhamri and Threadgold, Terry R. (2008). "Towards the professionalisation of public relations in Malaysia: Perception management and strategy development". Public Relations Review. 34: 285-287.

Akbulut, Deniz (2008). İş İlanlarında Halkla İlişkiler Mesleğinin Sunumu. Yayınlanmamış Yüksek Lisans Tezi, Kocaeli Sosyal Bilimler Enstitüsü.

Bowen, Shannon A. (2003). "I Thought It Would Be More Glamorous: Preconceptions And Misconceptions Among Students in The Public Relations Principles Course". Public Relation Review. 29(2): 199-214.

Bowen, Shannon A. (2009). "All Glamour, No Substance? How Public Relations Majors And Potential Majors In An Exemplar Program View The Industry And Function”. Public Relations Review (35): 402-410.

Brown, Kenon A., White, Candace L. and Waymer, Damion (2011). "African-American Students' 
Perceptions of Public Relations Educational Practice: Implications for Minority Recruitment". Public Relations Review (37): 522-529.

Bülbül, A. Rıdvan (2004). Halkla llişkiler. 2.b. Ankara: Nobel.

Cameron, Glen T., Sallot, Lynne M. and Lariscy, Ruth Ann Weaver (1996). "Developing Standards of Professional Performance in Pubic Relations". Public Relations Review. 22. No.1: 43-61.

Canpolat, Nesrin (2013). "Türkiye'de Halkla Illişkiler Eğitimi: Halkla İlişkiler Ders Programlarının Değerlendirilmesine Yönelik Bir Araştırma”. Gümüşhane Üniversitesi Illetişim Fakültesi Elektronik Dergisi. Cilt 2. Sayı:2.

Chappelow, Marsha A. (2015). "Standards for Educational Public Relations and Communications Professionals”. Journal of School Public Relations. Vol. 36: 421-443.

Clair, Robin Patrick (1996). "The Political Nature of the Colloquialism, "A Real Job": Implications for Organizational Socialization". Communication Monographs. Vol. 63. Issue 3: 249-267.

Coombs, W. Timothy and Rybacki, Karyn (1999). "Public Relations Education: Where is The Pedagogy?". Public Relations Review. 25(1): 55-63.

Cutlip, Scott M.and Center Allen H. (1978). Effective Public Relations. Englewood Cliffs. New Jersey: Prentice-Hall.

Doğru, Yusuf Bahadır (2016). "Web Sözlüklerinde Halkla Ilişkiler Mesleğinin ve Kavramının Algılanışı ve Temsili. Halkla İlişkilerde Uzmanlaşma III”. Nihal Paşalı Taşoğlu (Ed). Kocaeli: Umuttepe.

Durmuş, Beril, Yurtkoru, E. Serra ve Çinko, Murat (2011). Sosyal Bilimlerde SPSS'le Veri Analizi. 4. Basım. İstanbul: Beta.

Erdoğan, İrfan (2008). Teori ve Pratikte Halkla Ilişskiler. 2.b.Ankara: Erk.

Erzikova, Elina and Berger, Bruce K. (2011). "Creativity Vs. Ethics: Russian And U.S. Public Relations Students' Perceptions Of Professional Leadership And Leaders". Public Relations Journal. 5(3): 1-24.

Fullerton, Jami A. and McKinnon, Lori (2015). "U.S. Public Relations Students' Perceptions Of PR: What College Students Think About PR Education And The PR Profession". Public Relations Journal. 9(2). http://www.prsa.org/Intelligence/PRJournal/Vol9/No2. Erişim tarihi: 20.06.2017.

Gallicano, Tiffany Derville and Stansberry, Kathleen (2011). "Communication With Diverse Audiences Through A Case Study Approach". Public Relations Review (37): 556-561.

Gleeson, Damian John (2013). “Undergraduate Students' Perceptions Of Public Relations: An Australian Study". PRism. 9(1). http://www.prismjournal.org/homepage.html. Erişim tarihi: 17.06.2017.

Gonçalves, Gisela, Spínola, Susana de Carvalho and Padamo, Celma (2013). "Analysing Public Relations Education Through İnternational Standards: The Portuguese Case". Public Relations Review (39): 612-614.

Gower, Karla K., and Reber, Bryan H. (2006). "Prepared For Practice? Student Perceptions About Requirements And Preparation For Public Relations Practice". Public Relations Review. (32): 188-190.

Grunig, James E. (1989) Teaching Public Relations in the Future. Public Relations Review. 15 (1): 12-24. 
Grunig, James E. and Hunt, Todd (1984). Managing Public Relations. New York: Holt, Rinehart and Winston.

Grunig, James E. (2005). Halkla İlişkiler ve Illetişim Yönetiminde Mükemmellik. İstanbul: Rota.

Güllüpınar, Hasan (2015). "Stratejik İletişim Bağlamında Türkiye'deki Halkla İlişkiler Bölümlerinin Ders Müfredatları Üzerine Bir İnceleme”. e-Gifder. Cilt:3. Sayı 1: 17-35.

Kazancı, Metin (2002). Kamuda ve Özel Kesimde Halkla Ilişkiler. Ankara: Turhan.

Kruckebeg, Dean (1998) "The Future of PR Education: Some Recommendations". Public Relations Review. 24 (2): 235-248.

L'Etang, Jacquie and Pieczka, Magda (2002). Halkla Ilişkilerde Eleştirel Yaklaşımlar. Ankara: Vadi.

Okay, Ayla ve Okay, Aydemir (2007). Halkla Illişkiler Kavram Strateji ve Uygulamaları, 3.b. İstanbul: Der.

Okay, Ayla ve Okay, Aydemir (2008). "Türkiye'de Lisans ve Lisansüstü Halkla İlişkiler Eğitimi: Tezlerin Halkla Illişkiler Alanına Katkısının Kantitatif Bir Çalışması (1984-2007)". Selçuk Illetişim. Cilt 5. Sayı 2: 5-14.

Öksüz, Burcu (2015). "Halkla İlişkilerde Meslekleşme Sorunu". Illetişim Kuram ve Araştırma Dergisi. Gazi Üniversitesi İletişim Fakültesi. Sayı 40: 249-265.

Özen, Ercan ve Kılınç, Filiz (2015). "Işsetmelerde Finansal Performansın Artmasında Halkla İlişkilerin Rolü ve Halkla İlişkiler Algısı". Optimum Ekonomi ve Yönetim Bilimleri Dergisi. 2 (1): 147-170.

Park, Joosuk (2003). "Discrepancy Between Korean Goverment ond Corporate Practitioners Regarding Professional Standards in Public Relations: A Co-Orientation Approach". Journal Of Public Relations Research (15): 249 - 275.

Peltekoğlu, Filiz Balta (2007). Halkla İlişkiler Nedir. 7.b. İstanbul: Beta.

Phyllis, V. Larsen and Len-Rios, Maria E. (2006). "Integration Of Advertising And Public Relations Curricula:A 2005 Status Report Of Educator Perceptions". Journalism \& Mass Communication Educator. 61(1): 33-47.

Pira, Aylin (2004). "Bir Halkla İlişkiler Hedef Kitlesi; Halkın Tamamı veya Büyük Bir Kısmı Olarak Kamu; Kavramsal Çerçeve". Manas Üniversitesi Sosyal Bilimler Dergisi. Sayı: 6. Cilt: 12. ss.225234.

http://journals.manas.kg/mjsr/oldarchives/Vol06_Issue12_2004/409.pdf. Erişim Tarihi: 03.06.2017.

Sallot, Lynne M.., Cameron, Glen T. and Lariscy, Ruth Ann Weaver. (1998). "Pluralistic Ignorance and Professional Standards: Underestimating Professionalism of Our Peers in Public Relations". Public Relations Review. 24-1, No.1: 1-19.

Smith, Brian G. and Navarro, Jessica (2014). "Integrating Public Relations Education? An Analysis of Educator Perceptions of Integrated Communication Pedagogy". International Journal of Integrated Marketing Communications. Spring. 7-17.

Stacks, Don W., Botan, Carl. and Turk, Judy VanSlyke. (1999). "Perceptions of Public Relations Education". Public Relations Review. 25(1): 9-28. 
Sha, Bey-Ling (2011). "2010 Practice Analysis: Professional Competencies and Work Categories in Public Relations Today". Public Relations Review. 37: 187-196.

Solmaz, Başak, Arslan, Aynur, Aydın, Bayram Oğuz ve Duğan, Özlem (2012). "Türkiye'de Halkla İlişkiler Lisans Eğitimi Üzerine Bir Değerlendirme”. Selçuk Üniversitesi Sosyal Bilimler Enstitüsü Dergisi. Sayı 27.

Toth, Elisabeth (1999). "Models for Instruction and Curriculum Models". Public Relations Review. 25(1): 45-53.

Toth, Elisabeth L. and Aldoory, Linda (2010). "A First Look: An in- Depth Analysis of Global Public Relations Education, NewYork: Commission on Public Relations Education". http://www. commpred.org, Erişim Tarihi: 12 Mart 2017.

Tsetsura, Katerina (2011). "Is Public Relations a Real Job? How Female Practitioners Construct the Profession". Journal of Public Relations Research. 23(1): 1-23.

Tuncer, M. Umut (2011). "Halkla Illişkilerde Meslek Standartları: Uygulayıcılara Yönelik Bir Araştırma". İletişim Kuram ve Araştırma Dergisi. Gazi Üniversitesi İletişim Fakültesi. Sayı 32: $63-85$.

Ural, Ebru Güzelcik (2012) "Etkili Bir Halkla Ilişkiler Lisans Eğitimi için Halkla Ilişkiler Alanında Ortaya Çıkan Değişimlerin Eğitime Aktarılması”. e-Journal of New World Sciences Academy. Vol: 7, No: 2.

Vercic, Dejan, Van Ruler, Betteke, Butschi, Gerhard and Flodin, Bertil (2001) "On The Definition Of Public Relations: A European View". Public Relations Review. Volume 27. Issue 4. Winter: 373-387.

Vural, Beril Akıncı ve Yurdakul, Nilay Başok (2004). "Halkla ilişkiler Eğitiminde Müfredat ve Uygulamalar: Türk ve Amerikan Üniversitelerine Yönelik Kıyaslamalı Bir Çalışma”. International Symposium Communication in the Millennium A Dialogue Between Turkish and American Scholars. 17-19 Mart, İstanbul.

White, Candace and Park, Joosuk (2010). "Public Perceptions of Public Relations". Public Relations Review. 36: 319-324.

Yazıcı, Tülay ve Ekinci, Deniz Keba (2016) "Halkla Ilişkiler Uzmanlarının Halkla Ilişkiler Eğitimine Bakış Açısı”. Halkla Ilişkilerde Uzmanlaşma-III”. Nihal Paşalı Taşoğlu (Ed). Kocaeli: Umuttepe.

Yıldırım, Gonca ve Becan Cihan (2017). "Öğrencilerin Halkla İlişkiler Eğitimine Yönelik Tutumlarına ve Meslek İmajını Oluşturan Faktörlerin Belirlenmesine Illişkin Bir Değerlendirme: Halkla İlişkiler Bölümü Öğrencilerine Yönelik Bir Saha Araştırması”. JASS. International Journal of Social Science, Autumn I. Number: 59: 269-295.

Yenğin, Hülya (2004). Halkla İlişkilere Başlarken. İstanbul: Gamze.

European Communication Monitor 2007/ 2009/2011/2016 Raporları, www.communicationmonitor. eu/_Erişim tarihi: 27 Temmuz 2017. 